\title{
Analysis of Density and Distribution Patterns in Chrysophrys auratus (Pisces: Sparidae) Within a Reef Environment: An Experimental Approach
}

\author{
P. D. Kingett and J. H. Choat* \\ Marine Research Laboratory, R. D. Leigh, New Zealand and Department of Zoology, University of Auckland, Private Bag, \\ Auckland, New Zealand
}

\begin{abstract}
Density estimates for the fish Chrysophrys auratus (Forster) were obtained within a shallow subtidal reef system in North-eastern New Zealand by transect counts. The mean density in 6 reef areas during December 1978 varied from 2.8 to 139 individuals $500 \mathrm{~m}^{-2}$. The time of day at which counts were made did not influence our estimates of density. A further series of replicated counts in 7 reef areas from December 1978 to April 1980 revealed large seasonal differences in density. These differences resulted from a summer influx of first year $\left(0^{+}\right) \mathrm{C}$. auratus into the reef system. Peak densities of $0^{+}$individuals exceeded 250 ind $500 \mathrm{~m}^{-2}$ in some reef areas. In autumn and winter the density of $0^{+}$individuals dropped to less than $5 \mathrm{ind} .500 \mathrm{~m}^{-2}$ This influx of $0^{+}$individuals was recorded in both 1979 and 1980. Older individuals showed no seasonal trends in density. During summer a positive exponential relationship was detected between the percentage cover of the turfing alga Corallina officinalis and the density of $0^{+}$Chrysophrys auratus $(n=11, r=0.79)$. These fish fed in the Corallina turf. Experimental removal of replicated $25 \mathrm{~m}^{-2}$ areas of $C$. officionalis resulted in a 50 to $70 \%$ decline in fish feeding rates. At adjacent uncleared control sites there was no significant change in feeding rate, but aggressive interactions between $0^{+}$fish showed an increase ranging from 58 to $217 \%$. These results suggest that $0^{+} \mathrm{C}$. auratus defend local feeding sites over areas of Corallina turf.
\end{abstract}

\section{INTRODUCTION}

Spatial variation in fish distribution within a temperate reef system may be high, and related to specific features of the reef (Russell, 1977; Leum and Choat, 1980; Ayling, in press). However, the consistency of such distribution patterns may possibly vary according to season or between years.

The problem is to explain these local biases by identifying causal factors and examining their basis. However, before this is possible, detailed information on the local spatial and temporal patterns of distribution and abundance is required. Once factors that covary with such patterns have been identified, manipulative experiments to test for causal relationships can be carried out. The shallow reefs of north-eastern New Zealand and the species of fish associated with them, are ideal for such an approach.

The specific aims of this study were to detail the

- Addressee for reprint requests spatial and temporal patterns of distribution and abundance in the temperate fish Chrysophrys auratus (Pisces: Sparidae) at one locality and to examine and test factors that may be responsible for their variability within a reef. This was sought to answer the following questions:

(1) Is there uniformity in the distribution of Chrysophrys auratus in the reef at any one point in time?

(2) Does this species show any age specific or seasonal trends of distribution within the reef system?

(3) Are local patterns associated with particular features of the reef environment?

(4) Would manipulation of these features cause changes in these patterns within a reef area?

We regularly sampled the reef population in a variety of biologically and physically distinct areas, identifying which factor(s) correlate with biases in distribution and then manipulating the factor(s) to determine if a causal relationship exists.

Previous information on Chrysophrys auratus has come almost exclusively from trawl-caught individuals 
since this species supports an extensive trawl and long-line fishery. The information consists of descriptions of the species reproductive cycle (Crossland, $1977 a$, b), demography (Paul, 1976; Vooren and Coombs, 1977), and feeding relationships (Godfriaux, 1969, 1970; Colman, 1972). There is little specific information on changes in population structure that has not been gathered by trawl methods, though fishing pressure has an influence on abundance (Paul, 1974; Tong, 1978; Elder, 1979). C. auratus is large and feeds on benthic animals; hence it may modify the benthic invertebrate fauna and play an important role in reef dynamics.

\section{STUDY AREA}

This work was carried out at Goat Island Bay adjacent to the University of Auckland's Marine Laboratory $\left(36^{\circ} 15^{\prime} \mathrm{S}, 174^{\circ} 45^{\prime} \mathrm{E}\right)$. Fig. 1 shows the locality of the 7 areas sampled. They represent the range of physically and biologically distinct areas (Gordon and Ballantine, 1976; Russell, 1977; Leum and Choat, 1980; Ayling, in press) and vary from a deep, sandy bottom at Sponge Flats (G) to shallow broken rock and algal-covered boulders at Inner Waterfall Reef $(F)$.

\section{MATERIAL AND METHODS}

The age structure of the study population was assessed by examining the relationship between the number of annuli on scales and standard lengths of 80 Chrysophrys auratus. This method had previously been described in detail by Paul (1976) though he used fork lengths. We obtained a consistent relationship where standard length comprised $86 \pm 2 \%$ of the fork length for all collected sizes of $C$. auratus. Seasonal differences in length/age relationship were accommodated by collecting 45 fish between 24 November 1978 and 26 January 1979, and a further 35 fish between 3 July 1979 and 19 August 1979.

Density estimates for 6 areas (Fig. 1 A, B, C, D, E, G) within the reef system were obtained during the period 12-24 December 1978 and over 3 time periods: 05.30-10.00 h, 11.00-14.00 h, 16.00-20.00 h. Five replicated counts were made at each area, during each time period, giving a total of 90 counts over the $12 \mathrm{~d}$. All density data were estimated by visual counts over $50 \mathrm{~m} \times 10 \mathrm{~m}$ transects using SCUBA (Leum and Choat, 1980).

Seasonal changes in density were estimated for 7 areas (Figs 1 and 3), from 12 December 1978 to 23 March 1980. Nine to 11 density estimates were made at each area over this time period, with 5 replicate counts

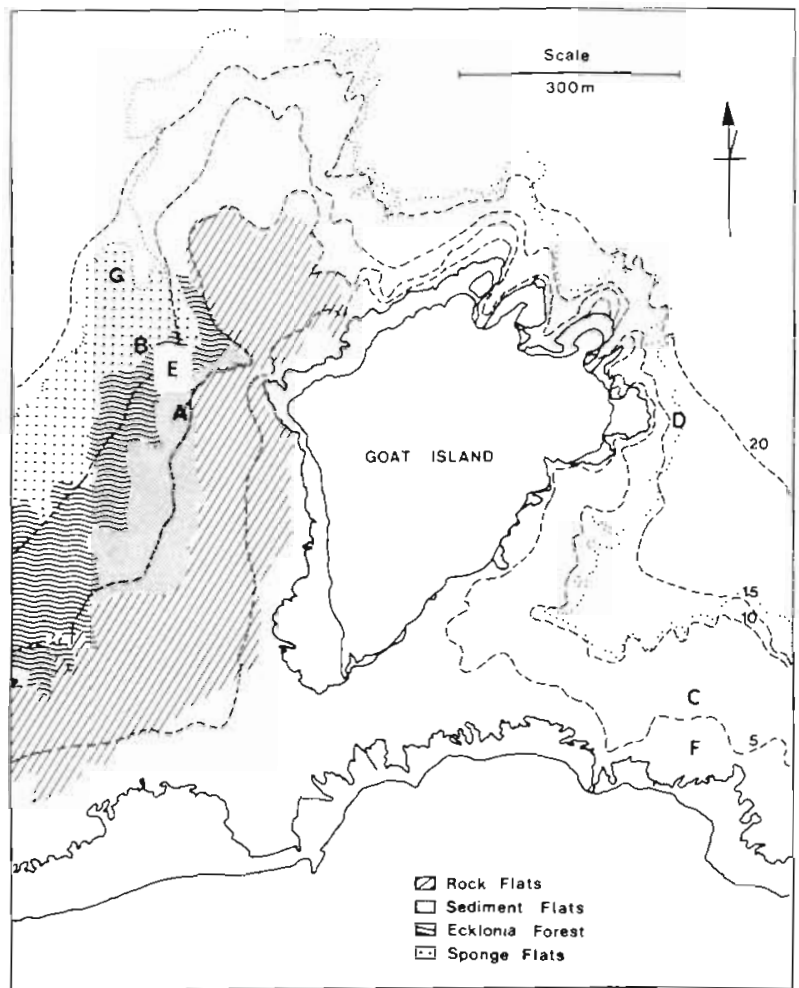

Fig. 1. Chrysophrys auratus. Goat Island Bay study area showing the 7 localities where visual counts of this fish were made during the sampling period. Included in the figure is an example of the extent and boundaries of the main substrata types with which $C$. auratus are associated. $A: P_{1}$ Sediment Flats; B: PB Ecklonia Forest/Sponge Flats Border; C: Mid Waterfall Reef Flats; D: Goat Island Point; E: PB 1 Ecklonia Forest; F: Inner Waterfall Reef; G: Sponge Flats

made each time, giving a total of 335 counts over the 16 mo period. Although counts were restricted to periods when underwater visibility was in excess of $6 \mathrm{~m}, 0^{+}$and $1^{+}$age classes were probably underestimated, especially when at high densities. This was due to these age classes forming dense, localised schools that move rapidly over areas of flat substratum. Initially areas of overhangs and dense algal growth were carefully searched for secretive individuals but this did not increase density estimates within an area.

The percentage cover sediment turf was estimated by randomly placing a $1-\mathrm{m}$ square quadrat, divided into $10010-\mathrm{cm}$ squares on the substratum and counting the number of squares covering the sediment turf. This was replicated 10 times within each area and repeated for 11 areas. Over the same period (18 January-20 January 1980) estimates of density for each age class of Chrysophrys auratus were obtained for the same 11 areas.

To examine the relationship between juvenile $\left(0^{+/}\right.$ $1^{+}$), sexually immature Chrysophrys auratus (Crossland, $1977 \mathrm{a}, \mathrm{b})$, and coralline turf, observations were carried out at Mid Waterfall reef flats from 11-14 
February 1980. Six sites, $5 \mathrm{~m} \times 5 \mathrm{~m}$, were marked on the substratum by fixing small plastic discs to the corner of each site and running a white nylon cord around the periphery. The cord was left in place only during periods of observation. Each site was at the same depth, had similar substratum topography, and was equally placed from shelter such as boulders and kelp. Selection of this area, rather than areas of higher $0^{+} / 1^{+}$density, was based on the heterogeneous nature of the substratum. This was the only area where 3 substratum types were present in close proximity to one another (Fig. 5), and which still had high densities of juvenile fish.

The number of feeding pecks and intraspecific aggressive interactions that occurred over a $20 \mathrm{~min}$ observational period were recorded for each age class. Divers worked in pairs, each watching a separate site. This was repeated 7 times for each site and the data pooled. This gave the position of feeding and associated behaviour within a site relative to the substratum types described in Fig. 5 after a total of 840 min of observation.

Removal of coralline turf from 3 sites was by divers using wire brushes and spatula scrapers during 15-24 February 1980. Chrysophrys auratus showed no signs of moving away from the disturbance caused by this activity. The area was left to settle for a week so as to preclude disturbance from influencing results. Observations were repeated as above with 720 -min observational periods at each site, totalling a further $840 \mathrm{~min}$ of observation.

\section{RESULTS}

\section{Patterns of Distribution and Abundance}

Samples of Chrysophrys auratus were used to establish a relationship between size and age of fish at our study sites (Table 1). A pooled size frequency distribution of individuals from the reef area shows that the majority $(82 \%)$ were between $60 \mathrm{~mm}$ and $130 \mathrm{~mm}$ standard length (Fig. 2). This corresponds to the $0^{+}$and $1^{+}$age classes (Table 1). The January 1979 peak of individuals between 90 and $100 \mathrm{~mm}$ standard length represents the $0^{+}$cohort that had a mean length of $85.11 \mathrm{~mm}$ in August 1979 (Table 1).

Spatial and diurnal variation in densities of Chrysophrys auratus were compared between 6 reef areas (Fig. 1 A, B, C, D, E, G), and 3 time periods during December 1978. Four age classes were identified (Table 2). The data were transformed (log e) and subjected to a three factor analysis of variance (factors; sampling area, time of day, age class). Areas, age classes and their interaction (areas $x$ age classes) were significant (Table 3). Time of day and the remaining interactions were non-significant $(\mathrm{p}>0.05)$.

The $0^{+}$age class attained densities higher than older $\left(1^{+}, 2^{+}, \geqslant 3^{+}\right)$individuals in 6 areas (Table 2$)$. The significant difference in density between areas was due to these $0^{+}$fish attaining very high numbers in some areas (Table 2, A, B). Older fish showed less pronounced differences in density over the same areas. Furthermore, this relationship between age structure, density and area was not modified by the time of day at which the counts were made (Table 3 ).

Evidence for seasonal changes in density was obtained by extending the sampling period over 16 months in 7 areas (Fig. 1). Clear seasonal trends in Chrysophrys auratus density were observed (Fig. 3). The magnitude and pattern of these were dependent on the age of the fish and the area sampled. In most areas the $0^{+}$age group showed strong summer peaks of abundance (January to March), contrasting with virtual absence in winter (May to August). Two reef

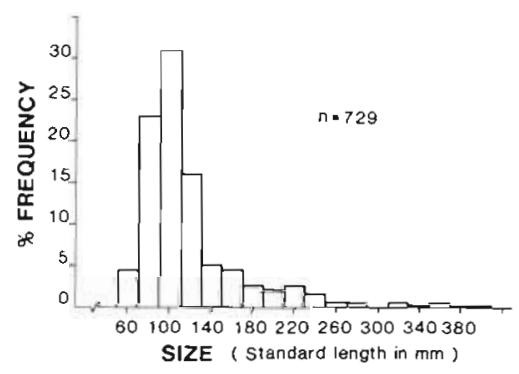

Fig. 2. Chrysophrys auratus. Size frequency at Goat Island Bay. Pooled from 80 ind. $500 \mathrm{~m}^{-2}$ counts at 6 areas during January 1979

Table 1. Chrysophrys auratus. Relationship between mean size (mm S.L.) and number of annuli on scales. November 1978, $n=45$. August $1979, n=35$. In this and subsequent tables the variance is expressed as the standard error of the mean

\begin{tabular}{|c|c|c|c|c|c|c|c|c|c|c|}
\hline \multirow[t]{2}{*}{ Time } & \multicolumn{10}{|c|}{ Number of annuli } \\
\hline & $\bar{x}$ & $S_{\bar{X}}^{\bar{x}}$ & $\bar{x}$ & $S \bar{x}$ & $\bar{x}$ & $S \bar{x}$ & $\bar{x}$ & $S \bar{x}$ & $\bar{x}$ & $S \bar{x}$ \\
\hline November 1978 & 83.3 & 11.7 & 103.5 & 2.6 & 145.0 & 2.9 & 192.3 & 4.1 & 221.4 & 8.0 \\
\hline August 1979 & 85.1 & 4.7 & 121.5 & 4.7 & 150.4 & 4.8 & 202.0 & 5.1 & - & - \\
\hline Pooled & 84.4 & 5.2 & 109.5 & 3.4 & 147.1 & 3.0 & 197.2 & 4.4 & 221.4 & 8.0 \\
\hline
\end{tabular}


Table 2. Chrysophrys auratus. Mean densities (no. ind $500 \mathrm{~m}^{-2}$ ) counted in 6 areas at Goat Island Bay during December 1978 . In each area 5 counts were made at 3 tıme periods: $05.30-10.45 \mathrm{~h} ; 11.00-14.00 \mathrm{~h} ; 16.00-20.00 \mathrm{~h}$ to give $n=15$ for each area

\begin{tabular}{|cl|}
\hline \multicolumn{1}{|c|}{ Type } & Description \\
\hline LIVING & \\
Massive & Unbranched coral colontes with rounded regular surfaces \\
Submassive & Unbranched coral colonies with irregular surfaces or protuberances \\
Thin ramose & Branched coral colonies with main branches $<10 \mathrm{~mm}$ thick \\
Medium ramose & Branched coral colonies with main branches $10-20 \mathrm{~mm}$ thick \\
Thick ramose & Branched coral colonies with main branches $>20 \mathrm{~mm}$ thick \\
NON-LIVING & Unconsolidated coral sand \\
Sand & Unconsolidated coral fragments \\
Rubble & Consolidated rubble and sand \\
Consolidated & Smooth consolidated surface often with thin layer of fine sand on top \\
\hline
\end{tabular}

Table 3. Chrysophrys auratus. Three factor analysis of variance (variable; density: factors; area, time of day, age class) on changes in density during 3 time periods at 6 areas. Data were $\log$ e transformed to reduce heterogeneity of variance

\begin{tabular}{|lrrrc|}
\hline Source of variation & DF & MS & F & P \\
\hline Area & 5 & 21.54 & 67.3 & $\ldots$ \\
Time of day & 2 & 0.01 & 0.02 & $\ldots$ \\
Age class & 3 & 74.97 & 234.4 & $\ldots$ \\
Area $\times$ time & 10 & 0.46 & 1.4 & $\ldots$ \\
Area $\times$ age class & 15 & 9.07 & 28.3 & $\ldots$ \\
Time $\times$ age class & 6 & 0.51 & 1.6 & \\
Area $\times$ time $\times$ age class & 30 & 0.39 & 1.2 & \\
Error & 288 & 0.32 & & \\
Total & 359 & 1.62 & & \\
$\cdots p<0.001$ & & & & \\
\hline
\end{tabular}

areas (Fig. 3, F, G) supported only small numbers of $0^{+}$ fish and no seasonal trends were apparent. The magnitude of change in density over the summer months differed markedly between reef areas with $\mathrm{PB}_{1}$ Sediment Flats (Area A) supporting the highest numbers of $\mathrm{O}^{+}$individuals. The changes in densities of this age class were often abrupt. For example, the decrease in $0^{+}$densities at $P B_{1}$ Sediment Flats (Area $A$ ) from a mean of 241 individuals in February 1979 to 45 individuals in March 1979 occurred over a period of $21 \mathrm{~d}$.

For older fish (Fig. 3, $1^{+}, \geqslant 2^{+}$) neither the pattern nor the magnitude of temporal change was comparable to those seen in $0^{+}$fish. Individuals exhibited an affinity for those reef areas which supported high densities of $\mathrm{O}^{+}$individuals but did not show the same pattern of seasonal changes (Fig. 3). Fish in the $\geqslant 2^{+}$age class, with the exception of those at $\mathrm{PB}$; Sediment Flats (Area A), showed little evidence of seasonal differences in density. A 3 factor analysis of variance (factors; area, age class, time) carried out on the $1^{\text {T}}$ and $\geqslant 2^{+}$densities (log e transformed) showed significant differences in density between areas $(p<0.01)$, and the times of sampling ( $p<0.05$ ), but not between the age classes. Interactions between area $\times$ time $(\mathrm{p}<0.001)$ and age class $\times$ time $(p<0.05)$ were also significant. Older fish also showed some numerical change, e.g. $2^{+}$individuals in areas D and F (Fig. 3). Here, an increase in density occurred in February 1979 and was sustained for 12 mo until February 1980, when a 4 -fold increase occurred.

It is possible that variable recruitment patterns could modify area and seasonal patterns of distribution and abundance observed in $0^{+}$individuals. To check for annual consistency in these patterns we sampled the 3 areas in which $0^{+}$and $1^{+}$fish had first been observed at relatively large densities (Figs 1 and $3 \mathrm{~A}, \mathrm{~B}, \mathrm{C}$ ). The size frequency data in Fig. 4 shows that over 3 years, $0^{+}$and $1^{+}$fish were present during February and that similar patterns of abundance were maintained between areas.

\section{Factors Influencing $0^{+}$Distribution}

We were unable to discern any correlation between numbers of Chrysophrys auratus of any age class and factors such as depth and topographic complexity (cf. Leum and Choat, 1980). For example, we found similar densities of $0^{\top}$ fish at one of the shallowest and most complex habitats, Inner Waterfall Reef, and at the deepest and virtually featureless Sponge Flats (Figs 1 and $3 F, G$ ).

More detailed observations on $0^{-}$fish showed that they were associated with a short dense turf of the alga Corallina officinalis. The mean percentage cover of this coralline turf in 11 areas was assessed at the same time as a series of summer (January 1980) counts of $0^{+}$ fish. There was a positive exponential relationship $(n=11, \quad r=0.79$ ) between Chrysophrys auratus densities in January "1980 and the mean percentage cover of coralline turf. 
Fig. 3. Chrysophrys auratus. Mean densities (ind. $500 \mathrm{~m}^{-2}$ ) with $95 \%$ confidence intervals for 7 reef areas from December 1978 to March 1980. Three age classes are distinguished. Five replicate counts were made in each area at each time. Note variation

in the density scale for each area

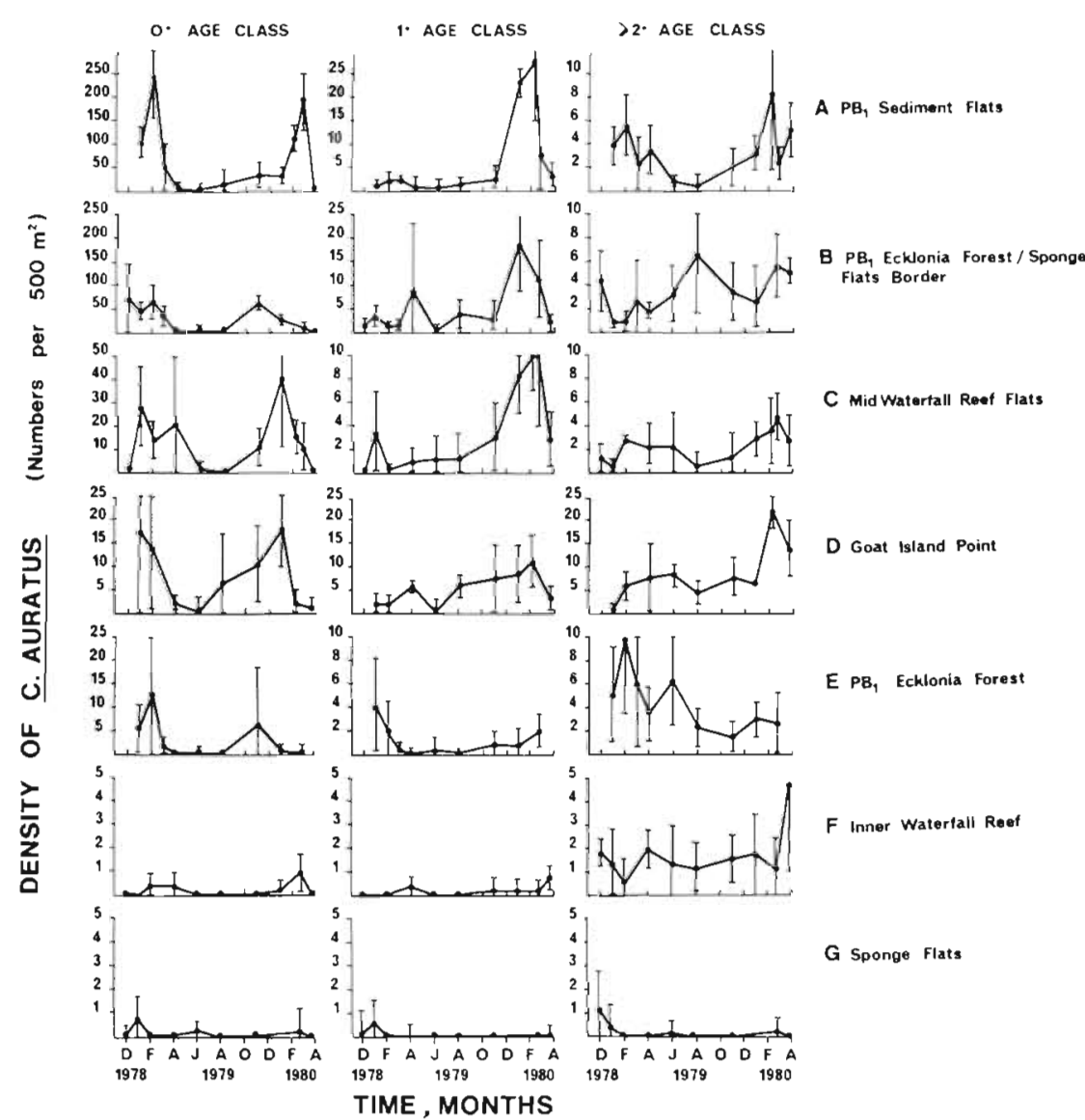

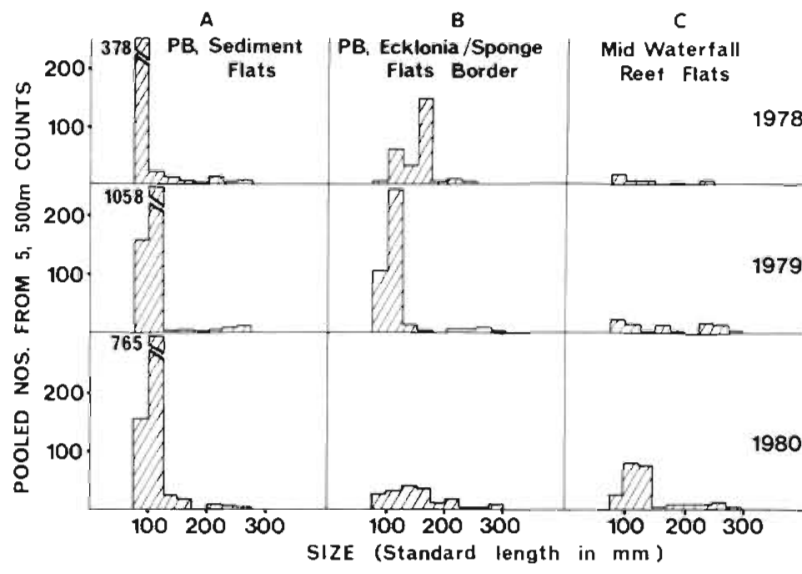

Fig. 4. Chrysophrys auratus. Size frequency at 3 areas during February 1978, 1979 and 1980. Abundance for each locality pooled from 5 ind. $500 \mathrm{~m}^{-2}$ counts

Very high densities of $0^{+}$fish only occurred over continuous homogeneous areas of turf (Figs 1 and $3, \mathrm{~A}_{\text {, }}$ B). To determine if this relationship had a biological basis we conducted a series of detailed observations on sites inhabited by $C$. auratus at Mid Waterfall Reef Flats (Fig. 1, C). These flats are characterised by both bare rock and coralline turf substrata and the presence of $0^{+}, 1^{+}$and $\geqslant 2^{+}$C. auratus (Fig. 4). For the purpose of these observations, two age groups were established: individuals $<140 \mathrm{~mm}\left(0^{+} / 1^{+}\right.$age classes $)$and those $\geqslant 140 \mathrm{~mm}\left(\geqslant 2^{+}\right.$age classes).

Feeding and associated behaviour were monitored at each site (Fig. 5). Individuals in the $0^{+} / 1^{+}$age group fed extensively at each site, but their feeding was concentrated almost exclusively on sections of coralline turf within a site. Intraspecific aggressive interactions, directed toward individuals of equal or smaller size, had their focus over the patches of coralline turf, and were associated with feeding episodes. There was relatively little feeding by $\geqslant 2^{+}$fish at these sites and, that which did occur, was directed toward the bare rock substratum.

These observations strongly suggested that the coralline turf constituted an important feeding resource for juvenile $\left(0^{+} / 1^{+}\right)$fish. As such, any change in the amount of the turf could have affected juvenile fish in one of two ways. Either their feeding and associated behaviour would have been modified or they would have utilized an alternative substratum with little or no change in feeding and behavioural activity.

An experiment was conducted to test these predictions. Three sites were randomly selected (Fig. 5 ONE, FOUR, SIX) as treatment sites and between $65 \%$ and $75 \%$ of the coralline turf removed from each. The 

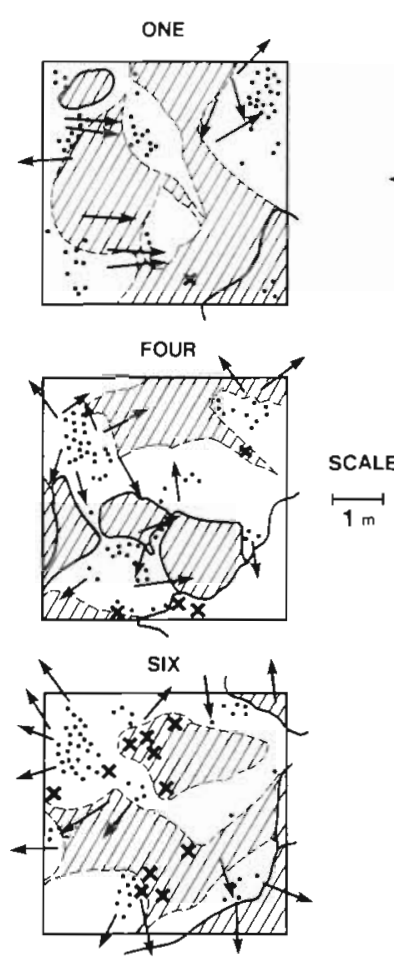

I CORALLINE TURF

Q7/2 BARE ROCK

DD7 SAND AND ROCK

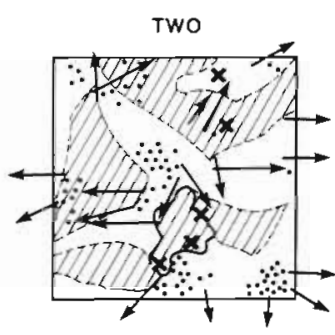

THREE

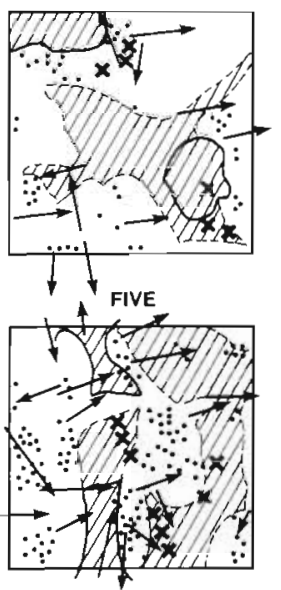

$\downarrow=0^{+} / 1^{+}$AGGRESSIVE

$x=\geqslant 2^{+}$PECKS

$\cdot=0^{+} / 1^{+}$PECKS
Fig. 5. Chrysophrys auratus. Feeding pecks and intraspecific aggressive interactions at Mid Waterfall Reef Flats. Pooled data from 7, 20-min observational periods at each site. Each site $(5 \times 5 \mathrm{~m})$ contains a range of substrata. Coralline turf comprises $32.3 \pm 2.4 \%$ of the substratum at each site. Only aggressive interactions within the $0^{+} / 1^{+}$age group shown. Base of arrow indicates where aggressive interaction was initiated, as well as the direction of retreating individual. Sites ONE, FOUR, SIX were selected as treatment sites; TWO, THREE, FIVE as controls

Table 4. Chrysophrys auratus. Turf removal experiment at Mid Waterfall reef flats during February 1980. The two variables feeding rate and aggressive interaction rate number in $20 \mathrm{~min}$ ) that occurred within the sites were analysed as the proportional change that occurred. Proportional change $=\frac{\text { No. after clearance }- \text { No before clearance }}{\text { No. before clearance }}$

\begin{tabular}{|c|c|c|c|c|c|}
\hline \multirow[t]{3}{*}{ Site } & \multirow[t]{3}{*}{ Site No. } & \multicolumn{4}{|c|}{$\begin{array}{l}\text { Proportional change } \\
\text { for } 0^{+} / 1^{+} \mathrm{C} \text {. auratus }\end{array}$} \\
\hline & & \multicolumn{2}{|c|}{$\begin{array}{l}\text { Feeding } \\
\text { rate }\end{array}$} & \multicolumn{2}{|c|}{$\begin{array}{c}\text { Interaction } \\
\text { rate }\end{array}$} \\
\hline & & $\bar{x}$ & $S \bar{x}$ & $\bar{x}$ & $S \bar{x}$ \\
\hline Control & 2 & -0.41 & 0.11 & 0.58 & 0.39 \\
\hline \multirow{2}{*}{ (Uncleared sites) } & 3 & 0.07 & 0.17 & 1.18 & 0.59 \\
\hline & 5 & 0.06 & 0.19 & 2.17 & 0.48 \\
\hline Treatment & 1 & -0.54 & 0.06 & 0.29 & 0.21 \\
\hline \multirow[t]{2}{*}{ (Cleared sites) } & 4 & -0.56 & 0.06 & -0.64 & 0.61 \\
\hline & 6 & -0.76 & 0.06 & -0.59 & 0.13 \\
\hline
\end{tabular}

Table 5. Chrysophrys auratus. One factor nested analysis of variance on the proportional changes in both varlables. The 3 sites are nested within each treatment; 7 replicate observation for each site

\begin{tabular}{|lrrrr|}
\hline Source of variation & DF & MS & F & P \\
\hline $\begin{array}{l}\text { (1) Feeding rate: } \\
\quad \text { Between treatments }\end{array}$ & 1 & 2.89 & 9.47 & $\cdot$ \\
$\quad$ Between sites & & & & \\
$\quad$ within treatments & 4 & 0.31 & 3.01 &. \\
$\quad$ Error & 36 & 0.10 & & \\
$\quad$ Total & 41 & 0.19 & & \\
(2) Interactions rate: & & & & \\
$\quad$ Between treatments & 1 & 27.96 & 8.66 & $\cdot$ \\
$\quad$ Between sites & & & & \\
$\quad$ within treatments & 4 & 3.23 & 3.40 &. \\
$\quad$ Error & 36 & 0.95 & & \\
$\quad$ Total & 41 & 1.53 & & \\
$\quad$ p $<0.05$ & & & & \\
\end{tabular}

remaining three sites (Fig. 5 TWO, THREE, FIVE) served as controls. A one-way analysis of variance showed there was no significant difference between the 6 sites in the percentage cover of coralline turf, feeding pecks and intraspecific interactions before manipulation of the coralline turf.

Subsequent to turf removal, the proportional change in the numbers of feeding pecks and aggressive interactions were calculated for treatment and control sites (Table 4 ). Because few $\geqslant 2^{+}$fish were recorded, they were not included. In sites where the coralline turf had been removed $0^{+} / 1^{+}$feeding rate dropped by more than $50 \%$, but in uncleared control sites the rate remained constant or dropped only slightly (Table 4). Aggressive interactions among these fish declined at cleared sites but increased markedly at control sites. However, proportional changes within treatment and controls were not all of uniform size and direction. The data were examined by a one-way nested analysis of variance to partition the within and between treatment variation (Table 5). Both feeding rate and interaction rate significantly differed between treatment and controls $(p<0.05)$. However, there was significant withintreatment variation, attributable to the anomalous events at Sites 1 and 2 .

Finally, we monitored the densities of Chrysophrys auratus over Mid Waterfall Reef Flats at the beginning and end of the experimental period. The density data (square root transformed) were analysed by a twofactor analysis of variance (factors; age class, time). Age was significant $(p<0.001)$ reflecting the higher densities of juvenile $0^{+}$fish, but neither time nor the age $\times$ time interaction was significant. We conclude that the density of fish and the population structure remained unchanged over the course of the experiment. 


\section{DISCUSSION}

Local patterns of distribution and abundance of Chrysophrys auratus show marked variation within the reef system around Goat Island. These differences are, in the main, due to the variation in $0^{+}$age class densities which change drastically between adjacent areas. For example, in $\mathrm{PB}_{1}$ Sediment Flats and $\mathrm{PB}_{1}$ Ecklona Forest (Fig. 1; A, E), in December 1978, $0^{+}$ densities were 132.75 and 4.46 ind. $500 \mathrm{~m}^{-2}$ respectively (Table 2 ); at the same time, their $2^{+}$densities were comparable: 3.00 and 2.26 ind. $500 \mathrm{~m}^{-2}$ respectively. Yet these adjacent areas are only metres apart. Moreover, distribution and abundance do not change over daylight hours for any age class within the reef system. This is in contrast to other groups of fish which may undergo size- or time-related movements or show increased activity at dawn or dusk (Obson, 1972, 1973; Ogden and Ehrlich, 1977; Gladfelter, 1979).

Temporal patterns showed the same kind of agespecific variation within areas of the reef system. $0^{+}$ individuals exhibited marked seasonal changes in density that occurred in most areas sampled. Individuals in this age group appear to leave the reef ecosystem entirely during winter. However, these areas are consistently reoccupied each summer, and over $3 y$, the pattern of relative abundances between areas was similar. In the other age groups investigated there was little evidence of seasonal changes of abundance. Older individuals $\left(\geqslant 2^{+}\right)$could be located in almost all areas year round, although there was considerable within-area variation.

The recent commercially orientated literature suggests that Chrysophrys auratus within the Hauraki Gulf are 'resident' (Paul, 1967), though Crossland (1976) suggested that extensive movement (mean distance: $25.7 \mathrm{~km}$ ) occurs in large individuals, possibly associated with spawning. There is no information on such patterns occurring in younger fish. However, studies on tropical reef fishes suggest that young individuals, once present in an area, tend to remain there (Sale, 1975, 1976; Sale and Dybdahl, 1978). Instead, we observed an opposite trend with evidence for seasonal movement of juveniles, but not of larger individuals. It is possible that large $C$. auratus associated with shallow reefs behave in a way different from individuals in deeper non-reef environments.

Such patterns are in striking contrast with another large temperate, carnivorous, benthic-feeding fish, Cheilodactylus spectabilis, found in this reef system. Though both species show striking biases in densities between areas, small $C$. spectabilis tended to be secretive, restricted to shallow water and did not reach high densities in particular areas (Leum and Choat, 1980). The distribution of juvenile Chrysophrys auratus was not depth-related and $\mathrm{O}^{+}$individuals were highly conspicuous, forming dense schools in specific areas, particularly over coralline turf flats.

The correlation between $0^{+}$density and the amount of coralline turf suggested that this feature of the subtidal reef environment had an important influence on the distribution and behaviour of juveniles. These individuals were observed to confine their feeding to patches of coralline turf in an area of heterogenous substratum. A great deal of intraspecific aggression was observed between Chrysophrys auratus of equivalent age while engaged in feeding activities. It appears that juvenile $C$. auratus occupy defended feeding sites over specific areas of coralline turf and prevent other individuals, of comparable or smaller size, from feeding there.

Removal of coralline turf from the substratum caused a reduction in feeding by juveniles; these were not observed to feed on organisms inhabiting the bare rock surface. The increase in aggressive interactions recorded at nonremoval control sites was possibly due to the movement of $0^{+} / 1^{+}$fish from nearby experimental sites, to these control sites, and attempting to feed there. The large increase in aggressive interactions, but only slight increase in pecks at these sites suggests that they were not successful.

A number of features of our design suggests that these results should be treated with some caution. Firstly, it would have been desirable to have further series of control sites sufficiently far away from the clearance sites to preclude movement of fish between treatment and control sites. However, such sites would have to be carefully selected so as not to confound other variables. As we were unsure of the outcome of this experiment we initially placed experimental and control sites within the same area to control for possible confounding variables (Fig. 5). Secondly, though densities of all age classes did not alter during the experiment, subtle changes in distribution within the area may have occurred. The argument of movement by $0^{+} / 1^{+}$individuals away from cleared sites to neighbouring uncleared sites would be better supported by data on density changes within sites, before and after manipulation of the coralline turf substratum. A further experimental series incorporating these modifications is planned.

The possibility of links between fish predation, grazing invertebrates and algal abundance (Nelson and Vance, 1979; Vance and Schmitt, 1979) suggests we could make predictions about changes in reef ecosystems. Ayling (in press) has experimentally demonstrated that both echinoids (Evechinus chloroticus) and limpets (Cellana stellifera) can reduce the amount of coralline turf present on shallow reefs. The activities of grazers, such as echinoids, could exert an indirect 
influence on the density and distribution of Chrysophrys auratus, especially as E. chloroticus in the study area can reach high densities (Ayling, in press). In addition, older $C$. auratus consume both limpets and echinoids (Kingett, unpubl.), both of which are associated with bare rock rather than coralline turf (Ayling, in press).

However, there are a number of processes that may override the importance of such links. The initial input of juvenile Chrysophrys auratus, which have a planktonic stage, might vary independently of changes in invertebrate or coralline turf abundance. Densities of $0^{+}$fish have been high in some areas over the last $3 y$, but at present, we can make no prediction that this will continue. Moreover, the relationship between $0^{+} \mathrm{C}$. auratus and older age classes in the Goat Island Bay reef ecosystem is still obscure. We have no information on whether high densities of $0^{+}$fish could result in their subsequent movement to other reefs. Longer-term sampling, behavioural studies and the use of genetic markers (Smith et al., 1978; Smith, 1979), could provide a basis for examining these processes. Consequently, we would hesitate to invoke the role of fish predation as a consistent factor structuring benthic communities - until detailed, experimentally based cause-effect information has been obtained.

Acknowledgements. We wish to thank A. M. Ayling for numerous discussions concerning this work and for access to his survey information on the Goat Island Bay reef system. We are particularly grateful to P. Hardy for his assistance with diving and fish counts. L. Stocker, M. Kingett, N. Kirby, D. Trennery, $K$. Walls and $N$. Andrew also provided diving assistance. D. R. Schiel, B. McArdle, G. P. Jones and D. M Lambert, discussed several aspects of this work with us. Support for this study was provided by the Leigh Marine Laboratory, Ministry of Agriculture and Fisheries, Oceans Society of New Zealand, the Department of Zoology, University of Auckland, and the University of Auckland Grants Committee. W Ballantine provided logistic support for the diving programme. G. Batt assisted with the preparation of figures.

\section{LITERATURE CITED}

Aying, A. M. (in press). The role of biological disturbance in temperate subtidal encrusting communities. Ecology

Colman, J. A. (1972). Food of snapper Chrysophrys auratus (Forster). N. Z. Jl mar. Freshwat. Res. 6: 221-239

Crossland, J. (1976). Snapper tagging in North-east New Zealand, 1974; analysis of methods, return rates and movements. N. Z. Jl mar Freshwat. Res. 10: 675-686

Crossland, J. (1977a). Seasonal reproductive cycle of snapper Chrysophrys auratus (Forster) in the Hauraki Gulf. N. Z. Jl mar. Freshwat. Res. 11: 37-60

Crossland, J. (1977b). Fecundity of the snapper Chrysophrys auratus (Pisces: Sparidae) from the Hauraki Gulf. N. Z. Jl mar Freshwat. Res. 11.767-775

Elder, R. D. (1979). Equilibrium yield for the Hauraki Gulf snapper fishery estimated from catch and effort figures,
1960-1974. N. Z. J1 mar Freshwat. Res. 13: 31-38

Gladfelter, W. B. (1979). Twilight migrations and foraging activities of the copper sweeper Pempheris schomburgki (Teleostei: Pempheridae). Mar Biol. 50: 109-119

Godfriaux, B. C. (1969). Food of predatory demersal fish in the Hauraki Gulf. Food and feeding habits of snapper. N. Z. Jl mar. Freshwat. Res. 3: 518-544

Godfriaux, B. C. (1970). Food of predatory demersal fish in the Hauraki Gulf: Feeding relationships. N. Z Jl mar. Freshwat. Res. 4: 325-336

Gordon, D. P., Ballantine, W. J. (1976). Cape Rodney to Okakari Point Marine reserve. Review of knowledge and bibliography to December 1976. Tane 22 (Suppl.): 1-146

Hobson, E. S. (1972). Activity of Hawaiians reef fishes during the evening and morning transitions between daylight and darkness. Fish. Bull. U.S. 70: 715-740

Hobson, E. S. (1973). Diel feeding migrations in tropical reef fishes. Helgoländer wiss. Meeresunters. 24: 361-370

Leum, L. L., Choat, J. H. (1980). Density and distribution patterns in a temperatre marine fish, Cheilodactylus spectabilis (Cheilodactylidae) in a reef environment. Mar Biol. 57: 327-337

Nelson, B. V., Vance, R. R. (1979). Diel foraging patterns of the sea urchin Centrostephanus coronatus as a predator, avoidance strategy. Mar. Biol. 51: 251-258

Odgen, J. C., Ehrlich, P. R. (1977). The behaviour of heterotypic resting schools of juvenile grunts (Pomadasyidae). Mar. Biol, 42: 273-280

Paul, L. (1967). An evaluation of tagging experiments on the New Zealand snapper Chrysophrys auratus (Forster) during the period 1952 to 1963 . N. Z. Jl mar. Freshwat. Res. 1: $455-463$

Paul, L. (1974). Hauraki Gulf snapper fishery, 1972 to 1977 : Some evidence for a declining catch rate. N. Z. Jl mar. Freshwat. Res. 8: 569-587

Paul, L. (1976). A study on age, growth and population structure of the snapper Chrysophrys auratus (Forster) in the Hauraki Gulf, New Zealand. Fish. Res. Bull. N. Z. Minist. Agric. \& Fish. 13: 1-64

Russell, B. C. (1977). Population and standing crop estimates for rocky reef fishes of North-eastern New Zealand. N. Z. Jl mar. Freshwat. Res. 11: 23-36

Sale, P. F. (1975). Patterns of use of space in a guild of territorial reef fishes. Mar. Biol. 29: 89-97

Sale, P. F. (1976). The effect of territorial pomacentrid fishes in the recruitment and survival of juveniles on patches of coral rubble. J. exp. mar Biol. Ecol. 24: 297-306

Sale, P. F., Dybdahl, R. (1978). Determinants of community structure for coral reef fishes in isolated coral heads at lagoonal and reef slope sites. Oecologia 34:57-74

Smith, P. J. (1979). Esterase gene frequencies and temperature relationships in the New Zealand snapper Chrysophrus auratus. Mar. Biol. 53: 305-310

Smith, P. J., Francis, R. I. C. C., Paul, L. J. (1978). Genetic variation and population structure in the New Zealand snapper Chrysophrys auratus (Foster). N. Z. JI mar. Freshwat. Res. 12: $343-350$

Tong, C. J (1978). Tagging snapper Chrysophrys auratus by scuba divers. N. Z. Jl mar. Freshwat. Res. 12: 73-76

Vance, R. R., Schmitt, R. J. (1979). The effect of predatoravoidance behaviour of the sea urchin, Centrostephanus coranatus, on the breadth of its diet. Oecologia 44: 21-25

Vooren, C. M., Coombs, R. F. (1977). Variations in Growth, Mortality and population density of snapper Chrysophrys auratus (Forster) in the Hauraki Gulf, New Zealand. Fish. Res. Bull. N. Z. Minist. Agric. \& Fish. 14: 1-32 